\title{
Discourse Analysis of the Palestinian Authority President Abbas' Address to the UN General Assembly in New York
}

\author{
Khader Tawfiq Khader ${ }^{1} \&$ Nisreen Hassouna ${ }^{2}$ \\ ${ }^{1}$ Department of English, Faculty of Arts, The Islamic University of Gaza, Palestine \\ ${ }^{2}$ Palestinian Council for International Relation, Gaza, Palestine \\ Correspondence: Khader Tawfiq Khader, Department of English, Faculty of Arts, The Islamic University of \\ Gaza, Palestine. Tel: 972-059-976-9504. E-mail: KKhader@iugaza.edu.ps
}

Received: June 2, 2015 Accepted: June 28, 2015 Online Published: July 30, 2015

doi:10.5539/ijel.v5n4p87

URL: http://dx.doi.org/10.5539/ijel.v5n4p87

\begin{abstract}
This study aims to spot the features of the Palestinian President's address to the UN General Assembly in New York from the perspective of discourse analysis.

The researchers utilized the descriptive approach where they used the following discourse analysis tools: that are context analysis, stylistic analysis and rhetorical analysis tool. All of these tools were applied to the study sample; president Abbas' address.

The results of study have shown that the sentences, ideas and expressions of the President are coherent and cohesive since he used a wide variety of pronouns (attached pronouns, first, second and third person pronouns) and connectors. Using such rhetorical devices, he built a common ground or understanding between the sender and receiver (President Abbas and the UN General Assembly). In addition, he used attached, detached, speaker and, absent pronouns and the conjunctions to help build a joint ground of understanding between the speakers and addressees and make the addressees join among the progressive meanings with each other imposing a significant impact to the members of UN General Assembly in New York.
\end{abstract}

Keywords: discourse analysis, style, address, language in politics

\section{Introduction}

Linguists use the term 'discourse' to denote a structural sequence of sentences which is viewed in terms of a wide range of activities. Analysis of discourse is necessarily the analysis of language in use (Khader, 2000). It is taken to be more than the investigation into the formal devices that connect sentences together. In this sense 'discourse' is to be regarded as a product of the language code and "discourse analysis" as an extension of the grammatical operation and description.

According to the Guy Cook, discourse is anything communicated-a speech, a conversation, a written note for a friend or an article in paper. Simply put, discourse is "language in use".

Brown and Yule (1983, p. 1) state that: "The analysis of discourse is, necessarily, the analysis of language in use. As such, it cannot be restricted to the description of linguistic form independent of the purpose of functions which these forms are designed to serve in human affairs."

The language experts George Yule (1996) and Gillian Brown (1983) claim, "the analysis of discourse ... cannot be restricted to the description of linguistic forms independent of the purposes or functions which those forms are designed to serve in human affairs". In other words, discourse analysis takes into consideration as many influencing factors as possible to arrive at an objective conclusion. While it is necessary to venture out to other fields, such as history, social studies, politics etc., to study discourse, scholars "must always be careful to return to the main concern" (Cook, 1989).

According to linguist David Crystal (1969), "we approach a text with various levels in mind and try to organize our material in their terms". Brown and Yule (1983) emphasize that the "discourse analyst necessarily takes a pragmatic approach to the study of language in use... That is, in using such terms as reference, presupposition, implicature and inference".

In addition, Thomas et al. (2004) define discourse as any piece of connected language, which contains more than 
one sentence. It is also sometimes used to refer specially to conversations. In sociology, it can be used refer to the way belief systems and values are talked about, as in "the discourse of capitalism". The prevailing way that a culture talks about or represents something is called the dominant discourse, that is the 'commonsense' or 'normal' representation.

Stubbs (1983) states that discourse analysis consists of attempts to study the organization of language above sentence or above the clause, and it, therefore, involves a study of larger linguistic units such as conversational exchange or written texts. It follows that discourse analysis is also concerned with the use of language in social contexts, and in particular with interactions or dialogues between speakers.

However, discourse or the study of discourse is not restricted only to the "actual instances of communication in the medium of language." (Johnstone, 2002, p. 2); it covers other "media of communication"; "it covers any significant semiotic event and system (mode).

Thus, the extended meaning of discourse is meant to count for those semiotic systems, devices, or elements.

Discourse analysis is a complex task, which can be accomplished by using various methods and approaches, depending on the user and his/her precise purpose of the analysis. This will be illustrated through this study.

The Palestinian Authority President Abbas' address to the UN General Assembly in New York represents an important step on the road to explain the Palestinian visions to resolve the Palestinian issue. This could be seen through analyzing the whole speech stylistically. Discourse analysis is a modern approach by which the elements of consistence could be identified as well as the language of speech that should be used. In addition, analysis of presidential speeches could help recognizing the way the speeches directed to the civilized communities and spotting the grammatical and stylistic structure. Moreover, it helps understanding all cultural, political, religious, spatial, chronological and social dimensions for the President's speech.

Unsurprisingly, the whole world and media agencies are giving great importance to the President's speech as it reflects the Palestinian situation including all complexity and ramifications.

This study investigates the stylistic features employed by the Palestinian president during his address to the UN General Assembly in New York from the perspective of discourse analysis. It aims to recognize the context and elements of consistence that include pronouns, demonstrative pronouns and connectors as well as repetitions exploring the grammatical and connotational levels besides the rhetorical aspects.

The significance of this study lies in the discourse analysis of the Palestinian Authority President Abbas' address to the UN General Assembly in New York. The results of this analysis add a unique value to fields of media, political and stylistic studies for it shows the aspects of how sophisticated speeches are best delivered.

\subsection{Problem Statement}

After reviewing the related literature, the researchers found that there is no specific study analyzing any of President Abbas' speeches. There is a need to analyze President's Abbas speech to figure out the linguistic approaches and speech strategies utilized by the president to address the public.

\subsection{Importance of Study}

The significance of this study lies in the discourse analysis of the Palestinian Authority President Abbas' address to the UN General Assembly in New York. This analysis has great importance in fields of media, political and stylistic studies for the following reasons:

- Scientific Importance: Arab libraries - especially the Palestinian ones-lack studies tackling President Abbas' speeches; therefore, this study enriches the Arabic library in this regard.

- Methodical Importance: the current study represents a paradigm for researchers who are interested in political discourse analysis and audience response.

- Linguistic Importance: through analyzing the elements of consistence and communication approach in the light of language used and its lexical, grammatical and stylistics aspects.

- In-depth assessment: through objective assessment of cultural, political, religious and social features of President Abbas' address to the UN General Assembly in New York.

\subsection{Objectives of Study}

The main objective of this study is to do a discourse analysis of the Palestinian Authority President Abbas' address to the UN General Assembly in New York. A set of sub-objectives emerge from the main objective as follow: 
a) Analyzing elements of consistence in President Abbas' address.

b) Analyzing President Abbas' address with respect to communication theory.

c) Exploring the plain and organized similes used in the Palestinian Authorities speech as being labeled widespread and powerful.

d) Studying the internal elements and ideas of the address and their connotations besides exploring the external factors that formed it.

e) Highlighting the rhetorical techniques used by the Palestinian President in his address to influence the audience.

\subsection{Questions of Study}

The following main question crystalizes the study objectives:

- What are the characteristics of President Abbas' address to the UN General Assembly in New York?

The following sub-questions emerged from the main questions:

- What are the rhetoric characteristics of President Abbas' address to the UN General Assembly in New York?

- How did President Abbas persuade the audience with his vision of peace and proposed solution for establishing the Palestinian State?

\subsection{Study Type, Approaches and Tools}

a) Type of Study

This study belongs to the descriptive studies that aim to visualize, analyze and assess the rhetoric characteristics of President Abbas's speech.

b) Approaches of Study

Due to the nature of study, which starts with characterization of the phenomenon under study and its aspects, the researcher applied the following approach:

\section{- Discourse Analysis Approach}

The discourse analysis approach involves an explanatory view of social reality. From the outset, this approach aims to identify the intellectual and ideological aspects that form an address over the course of any given time.

c) Tools of Study

In view of the nature, objectives and questions of the study, researchers combined between qualitative and quantitative approaches in order to benefit from both advantages. Using qualitative and quantitative approaches together help to achieve an accurate and inclusive analysis of the President's address as well as avoiding the disadvantages of using each of them separately. The used tools are as follow:

\section{- Critical Discourse Analysis Tools}

The researchers used three tools to analyze the president address:

a) Context analysis tool

It tackles the period of time and spatial domain, including the surrounding community.

b) Stylistic analysis tool

It, semantically, studies the wording and expression of ideas contained within the analyzed text.

c) Rhetorical analysis tool

It tackles the way rhetoric characteristics are used to serve specific objectives taking in consideration the importance of analyzing the text from lingual perspectives.

\subsection{Sample of Study}

The study sample, which is an intended one, includes the Palestinian Authority President Abbas' address to the UN General Assembly in New York. This sample assists to identify the nature of the address and its stylistic connotations in light of the circumstances surrounding the Palestinian cause.

\subsection{Unit of Analysis}

In this study, "Word" is the unit of analysis. 


\subsection{Method of Counting and Measurement}

Researchers use frequency of units as a method of counting and measurement.

\subsection{Test Reliability and Validity}

\section{- Reliability}

The researchers followed many steps to ensure the validity of results, including: clearly identifying the units of analysis and keywords, determining the measurement approach by which the address is segmented into units and taking into account objectivity and accuracy during the analysis.

\section{- Validity}

The test-retest reliability method was applied where the pronouns, word frequency and sentence structure were analyzed. The validity percentage of this study is about $95.2 \%$; this percentage is high when it comes to media studies and indicates the clarity and validity of study.

\section{Analysis of the Palestinian Authority President Abbas' address to the UN General Assembly in New York}

This section shows the results of analyzing the Palestinian Authority President Abbas' address to the UN General Assembly in New York using (Context analysis, Stylistic analysis and Rhetorical analysis).

\subsection{Context Analysis}

Title: Palestinian Authority President Abbas' address to the UN General Assembly in New York.

Speaker: Palestinian President Mahmoud Abbas.

Date: $27 / 09 / 2012$

Place: The UN General Assembly in New York.

Topic: The Palestinian demand for an independent state.

Content: The speech tackles a very important political topic about the recognition and establishment of the independent Palestinian state, which will be accomplished by a support from the international community and facing the Israeli occupation, which stands as the only hindrance for the establishment of the State of Palestine. The speaker used an effective style to influence the addressees' sentiments; he started the communication channel by the audio channel and he began his speech with "The president of the General Assembly of United Nations, the heads of delegations ... Ladies and gentlemen ...". The introduction contends that those mentioned play a crucial role in supporting the establishment of the Palestinian state. Moreover, the speaker started the speech with thanking the presidents and the delegations of the member countries who stressed-in their speeches - the necessity of progress towards achieving the just peace that would secure the thoughts of the Palestinian people. In addition, the speaker used the plural speaker pronoun (na - us) to share the senses of warmth, strong feelings, and the actions with the addressees; "na" as indicated to the entire Arabian world: he said, "tahqiq aslsalam fi manteqatena bima yuamin lisha'ab alfelasteeni huqoqahu alwataniya althabeta." (To achieve a just peace in our region so as to ensure the inalienable national rights of the Palestinian people).

Moving onto another topic, he talked about the exposure of the Israeli violations of the rights of the Palestinian people from the beginning of Nakba until the time address. He assures that the international community must be held responsible for that and quickly issue resolutions about the solution of the Israeli-Palestinian conflict. He ended his speech with very poignant words of explicit connotations and an effective piece of advice for the international community, telling them to stop a new Nakba in the Holy Land. He said, "I said the brave Palestinian people would never allow being a victim of a new Nakba. They will continue in their odyssey of steadfastness and their eternal survival on their good land. Our people insist on the peaceful popular resistance compatible with the international humanitarian law - against the occupation and settlement and on freedom, independence and peace."

\section{There are two purposes for the speech:}

The first: explicit purpose, which is to persuade the addressees of the validity and necessity of establishment of the Palestinian state.

The second: implicit purpose, which is to employ peace as a source of political power, to face the aggressive actions of the Israeli occupation against the Palestinian people as well as employing the Palestinian people's peaceful resistance which is compatible with the international humanitarian law against the occupation and settlement in order to gain freedom and independence. 


\subsection{Features of Consistency}

Its tools are included inside the text and outside the text.

\section{1) Pronouns}

Table 1. The frequencies and percentages of the pronouns in President Abbas' address

\begin{tabular}{lll}
\hline Pronoun & Frequency & $\%$ \\
\hline Detached Pronoun (howa: he, hiya: she) & 12 & 4.9 \\
First-Person Pronoun (naa: us, Nahn: we) & 53 & 21.7 \\
First-Person Pronoun (ni: me) & 2 & 0.8 \\
Attached Pronoun (h: him) & 37 & 15.2 \\
Attached Pronoun (ha: her) & 54 & 22.1 \\
Third Person (hm: them) & 32 & 13.1 \\
Total & 244 & 100 \\
\hline
\end{tabular}

The previous table shows that the attached pronoun (ha: her) is at the first place among the pronouns at $22.1 \%$ and its frequency is 54 , and the speaker pronoun (na: us; we: nahnu) is placed at the second status at $21.7 \%$, and its frequency is 53 . The attached pronoun (h: him) occupied the third place at $15.1 \%$, and a frequency of 37 , and the absent pronoun is at the fourth place at $13.1 \%$ and a frequency of 32 . After that, the detached pronoun (howa: he; hiya: she) gets the fifth place at $4.9 \%$ and a frequency of 12 , and finally the speaker pronoun has the seventh place at $0.8 \%$ and a frequency of 2 .

The attached pronoun (الضَّير المُنَّلِيل /ađ-đamīr al muttaŝil) [ha: her]:

President Abbas used the pronoun (ha) 54 times at different places, and that pronoun refers to a word posited in a previous sentence; therefore, will affect the addressee's understanding who will keep realizing the meaning and be influenced by it. That pronoun has sundry references. For instance, he said about the Israeli government (ha), "toreedu mowasalet ihtelalha lilqudsi alsharqiya" [it wants to keep occupying East Jerusalem], and he said, “... wasalat fardu hesaruha al khaniqu wa gharatuha wa I'ateda'ouha ..." [kept imposing its suffocating blocked, its raids and its attacks ...]. "Ha" refers to the Palestinian National Authority as in when he said, "... ifshaleha in alqiyam bi mahameha wa wathaefeha wa tanfeeth iltizamatiha ..." [... abort its objectives, its functions and implementing its commitments]. Also, in his speech "ha" refers to Jerusalem; he said, "alwosoul alhur ila masajeduha wa kanaesuha wa ila madaresuha wa mostashfayatuha wa aswaquha ..." [... the free access to its mosques, its churches, its schools, its hospitals, and its markets ...]", and it refers to the Peace Process as in "... inqathu amaliyat assalam takrees qawa'duha wa aususuha..." [... to save the peace process by establishing its foundations and its rules ....] Generally, it refers to Nakba (disaster) like "ya'rifoun tafaseel waqa'ha hgraheeba ..." [they know the details of its terrifying chronicles].

The speaker (first person) (المُنَّك /al mutakallim) [na: us/our; nahnu: we]:

The president Abbas has mentioned this pronoun 53 times at different places, for example, "masajiduna (our mosques), kna'isuna (our churches), iqtisaduna (our economy), mabad'una (our principles), qanaatuna ( our satisfaction), arduna (our land), ajouana (our sky), houana (our air), hodouduna (our borders), hoqoquna (our rights). The president used the pronoun to refer to himself as well as the Palestinian people in both the home and Diaspora. He also used it to represent the Palestinian people by being interested in establishing the independent Palestinian state and supporting the Palestinian demand of getting membership in the United Nations. Moreover, the president employed this pronoun - that denotes to the plural - to express all the Palestinian people with all their parties and leaders as though they are like one body, and he was repeating that in order to assure that the establishment of the independent Palestinian state is the demand of all Palestinian people.

\section{The attached pronoun (الضَّمير المُنَصِيل /ađ-đamīr al muttaŝil) [h: him]:}

The president Abbas used the attached pronoun (h) 37 times at different positions. The attached pronoun helps the reader to comprehend the connotation and become convinced of the proposed idea. For example, the " $h$ " refers to the Palestinian people as in, “... hm jinoud sha'behim fi nedaleh ...." [... they are the People's soldiers in their struggle ...], and "... sayowasel malhamet somoudeh wa baqa'h alabady fawqa ardehi altayiba ..." [it will keep his odyssey and his eternal survival on the his good land]. Sometimes it refers to the Israeli political discourse as in, "... khetab yaqoud fi katheer min jouanibehi wa fi tatbeqatihi al-amaliya ila mahawer al-sera" [this discourse and in many of its aspect and practical process leads to the shafts of conflict], and "... li drakana lima ya'neeh min ithkaa' alnar ..." [being aware of what it means to stoke the fire]. In addition, the pronoun 
refers to the international community in “... mataleb alyoum akthar min ay waqtin madha tahamul masou'liyateh ..." [The current demands of bearing the responsibility are more than before].

\section{The absent (third person) (الغائب /al ghā'ib)}

President Abbas employed the pronoun 32 times at different positions. All of them refer to the Palestinians, for example, “... hum yasunoona fi thakirtihim wa fi qolubehim althikrayat alhameema a'n aalamehim aljameel allathi domera ..." [they keep the friendly memories about their destroyed world in their memory and hearts ...], “... Li iqtela'ihim min ardehim ..." [uprooting from their land ...], and "... yatamaskoun behaqehim alensani almashroua' ..." [... they cling to their legitimate human right], "yarouna watanehim wa haaderihim wa moustqbalihim urdatan lilestelab ..." [they see their home, their present, and their future susceptible to pillage]. In addition, it refers to the settlers as in "... tassaeed almustawatineen le ?itedaatehim ..." [the settlers escalating their attacks], "tasaroua li itlaq sarahehim wa aoutuqil ahdon minhum ..." [quickly releasing them if they are suddenly captured]. He clearly used "hm" in the last sentences to express the neutrality: the Palestinians are the underdogs and the settlers are the aggressors ....

\section{The detached pronouns (الضَّمير المُنْفصِل /ađ-đamīr al munfaŝil/) [howa: he; hiya: she]}

The president Abbas used these pronouns 12 times at different positions; using these pronouns stresses on the coherence of the meaning and its progress from sentence to another. Strictly speaking, he used the pronoun (howa) to refer to the settlers and their attacks against the Palestinian people to show their persecution of the Palestinian people's rights and their perpetual assault against them, for example, “... tasaeed al moustawteneen ... howa netaj tabeea'i le istimrar ihtelalihim ..." [the settlers' escalation ... is a natural outcome of their progressive occupation ...], and "wa howa wlaeed shra'i lemonakh onsuri ..." [It is a legitimate neonate of racial climate]. On the other hand, "hiya" refers to "the state" to confirm the legitimacy and the Palestinian people's illegibility to establish their own state as in "dawla yajeb an tuqam hiya Felasteen ..." [the state that must be established is Palestine ....].

\section{The speaker (first person) (المُنَّلَّل /al mutakallim). (y: me)}

President Abbas used the pronoun twice to assert that the Palestinian people are angry at the tyrannical Israeli actions against the accordance of their rights, and the Palestinian people will continue their odyssey of resistance and survival on their good land, for instance, “... inni atahadathu bism shaa'b al ghadeb ..." [I speak on behalf of the angry people], and “... inna shaa'bi sayuwasel malhamat somodehi ...” [... my people will continue their odyssey of resistance ...]. The speaker pronoun (y) stands for the high confidence that the president has in his people and their resistance.

\section{2) The Demonstrative Pronouns}

Table 2. The frequencies and percentages of the demonstrative pronouns in President Abbas' address

\begin{tabular}{lll}
\hline The Demonstrative Pronouns & Frequency & $\%$ \\
\hline Hāthā (this) & 3 & 30 \\
Hāthihi (this) & 7 & 70 \\
Total & 10 & 100 \\
\hline
\end{tabular}

The table shows that the demonstrative pronoun (hāthihi) got the first place at $70 \%$ and frequency of 7 , and then hāthā has $30 \%$ and frequency of 3 .

The President employed — in his speech—-the demonstrative pronoun (hāthihi, hāthā) 10 times at different places. For instance, "... ghayra anna kul hāthihi almubadarat ..." [all these initiatives ...], “... inna hāthihi al injazat ..." [ these accomplishments ...], and “... nahnu fi hāthā almajal nada'u al mojtama' addawli ..." [... we at this level call the international community .... Employing such demonstrative pronouns will provoke the addressees to interact with them; because they join the pervious and the following, they contribute to the unity of the text and to be understood by the addressees. 


\section{3) Relative Pronouns}

Table 3. The frequencies and percentages of the relative pronouns in President Abbas' address

\begin{tabular}{lll}
\hline Relative Pronoun & Frequency & $\%$ \\
\hline Al-Lathī (who/that) & 4 & 21.1 \\
Al-Latī (who/that) & 9 & 47.4 \\
Al-lathīna (those all/ who (all)) & 6 & 31.5 \\
Total & 19 & 100 \\
\hline
\end{tabular}

The previous table shows that the relative pronoun (al-Latī) got the first place at $47.4 \%$ and a frequency of 9 . Then, (al-lathīna) got 31.5\% and a frequency of 6 . After that, (al-lathī) got $21.1 \%$ and a frequency of 4 .

The president Abbas used the relative feminine pronoun (al-Latī) and the masculine (al-ladhīna) and (al-ladhī), for example, “... jawhar almosalaha altarekhiya al-latī agtrahaha itefaq oslo..." [The essence of the historical reconciliation proposed by the Oslo Agreement], “... althulm attareekhi ghayr masbooq allathī urtukiba bihaqehim ..." [the unprecedented historical injustice against this right ], and “... tuwufiyat nesba kabeera min allathīna kanu dahaya mobashireen ..." [a lot of them, who were direct victims, died]. Using the relative pronoun points out to the connection between the referred and the adjective, and that will influence the meaning.

\section{4) Conjunctions}

Table 4. The frequencies and percentages of conjunctions in the speech of in President Abbas' address

\begin{tabular}{lll}
\hline Conjunctions & Frequency & $\%$ \\
\hline Wa (and) & 235 & 98.3 \\
Fa & 3 & 1.3 \\
Aw (or) & 1 & 0.4 \\
Total & 239 & 100 \\
\hline
\end{tabular}

The previous table shows that "wa" has the first place at $98.1 \%$ and a frequency of 235 . Then "fa" got $1.3 \%$ and a frequency of 3 . After that, "aw" got $.4 \%$ and a frequency of 1 .

The president used the conjunctions - wa, fa, and aw-that connect between the previous and following sentences, and that connection helps the addresses join the consecutive meanings among sentences. "Wa" is used 235 times at different situations, for instance, “... lam yakun tas?ed almustawtineen li i? teda'ehim wa la yajeb an yakoun amran mofaji'an ..." [that was not the settler's escalation and it must not be a sudden action], and “... wa nahnu fi hatha almajal nad?u almojtama' adduwali le ilzam alhukuma alisraeliya behtiram itefaqiyat Jeniv , wa tahqeeq fi thoruf iateqal alasra alatheena nushaded ala daroret al efraj anhum ..." [In this field we ask the international community to oblige Israel to respect the Geneva Conventions and to investigate the arrest conditions of the prisoners who we stress on releasing].

On the other hand, "aw" is mentioned once: "Aendma aouteeh lidowal alalam an toalin mawqifha ba'da an ay qoyoud aw naqss ..." [when the countries are permitted to announce their positions without any restrictions or lack of ...]. The other conjunction, "fa", is mentioned 7 times. "... La yajeb an ykoun amran mofajean le ahad, fahwa netaj tabe'i listimrar al-ihtilal ..." [that should not be surprising because it is a natural result of the continuous occupation ...], "nowasel madu ayadeena sadiqeen li alshaa'b al-israeli min ajli sun? assalam, fanahnu nodrek anahu fi nehayat almataf la buda ..." [we keep stretching our true hands to the Israeli people for the sake of peacemaking; we realize that the at the end we must ...], "wa fi alwaqt nafsuhu fina alsolta alfalsteniya akdat ..." [at the same time, the Palestinian Authority confirmed ...] , "endama utiha lidowal alalam an to'alin mawqifha ba'eedan ... faqad sawatat wa beqowa ..." [when the countries are permitted to announce their positions without ... they strongly voted ], “... wa lilhadaf nafsihi faqad badana moshawarat mokathafa ..." [for the same aim, we started intensive talks ], "al ?an 77\% min abna"a alsha'ab Al-felasteeny ..." [now 77\% of the Palestinian people , and “... almotajathera beha ?abr attarrekh, fala watan lana illa Filasteen ...” [rooted in it through history ... there is no home but Palestine...]. 


\section{5) The relation with the lexical terms}

\section{a) The repetition of key words:}

Table 5. The frequencies and percentages of the key words in President Abbas' address

\begin{tabular}{lll}
\hline The word & Frequency & $\%$ \\
\hline The Israeli Occupation & 29 & 23.9 \\
The Palestinian People & 22 & 18.2 \\
Peace & 18 & 14.9 \\
Racial Settlement & 9 & 7.4 \\
Establishment of State of Palestine & 7 & 5.8 \\
The Palestinian Authority & 6 & 4.9 \\
Nakba & 5 & 4.1 \\
Freedom & 4 & 3.3 \\
Jerusalem & 3 & 2.5 \\
War & 3 & 2.5 \\
Negotiations & 3 & 2.5 \\
Conflict & 3 & 2.5 \\
The United Nations & 3 & 2.5 \\
The West Bank & 2 & 1.7 \\
General Assembly & 2 & 1.7 \\
Its National Rights & 2 & 1.7 \\
Total & 121 & 100 \\
\hline
\end{tabular}

The previous table shows some of the repeated words in the speech; the repetition is to attract the attention and to clarify and contend the idea. "The Israeli occupation" was mentioned 29 times at $23.9 \%$ in Abbas's speech, getting the first place. Second, the "Palestinian people" has $18.2 \%$ and a frequency of 22 . Third, "peace" has $14.9 \%$ and a frequency of 18 . Fourth, "settlement" gets $7.4 \%$ and a frequency of 9 . Fifth, "establishment of the State of Palestine" gets 5.8\% and a frequency of 7. Sixth, "the Palestinian authority" gets $4.9 \%$ and a frequency of 6. Seventh, "nakba" gets $4.1 \%$ and a frequency of 5 . Eighth, "freedom" gets $3.3 \%$ and a frequency of 4 . Ninth, "Jerusalem", "war", "negotiations", "conflict", "the United Nations", have 2.5\% and frequency of 3. Lastly, "General Assembly", "the West Bank", and "the National rights" get 1.7\% and frequency of 2.

\section{b) The repetition of the synonyms and semi-synonyms of signifiers:}

Table 6 . The repetition of synonyms and semi-synonyms of signifiers

\begin{tabular}{|c|c|c|c|}
\hline Eradication and ethnic cleansing & $\begin{array}{l}\text { Extremely difficult if not } \\
\text { impossible }\end{array}$ & $\begin{array}{l}\text { To weaken the authority and } \\
\text { abort it }\end{array}$ & Torture and Abuse \\
\hline $\begin{array}{l}\text { To renounce the violence and reject } \\
\text { the terrorism }\end{array}$ & Our sky and air & $\begin{array}{l}\text { Our principles and } \\
\text { convictions }\end{array}$ & Barriers and walls \\
\hline Procrastination and delay & $\begin{array}{l}\text { Its freedom and } \\
\text { independence }\end{array}$ & $\begin{array}{l}\text { Proof of seriousness and } \\
\text { sincere intentions }\end{array}$ & Tightening the siege and restrictions \\
\hline Transparency and accountability & The simple normality & Clearly and on public & $\begin{array}{l}\text { It's not a hidden riddle nor intractable } \\
\text { puzzle }\end{array}$ \\
\hline $\begin{array}{l}\text { A country must be } \\
\text { established-Palestine }\end{array}$ & Established state is Israel & Its steadfastness and survival & Its foundations and basis \\
\hline $\begin{array}{l}\text { Impressive experience and success } \\
\text { story }\end{array}$ & Honest and sincere & $\begin{array}{l}\text { To be convicted and } \\
\text { punished and boycotted }\end{array}$ & To end and to leave \\
\hline
\end{tabular}

The previous table shows the repetition of synonyms and semi-synonyms of signifiers. To illustrate, "eradication and ethnic cleansing "stands for removing the organizations and the forced expulsions of the ethnic and religious communities from the areas at where they live. Regarding the Israeli-Palestinian conflict, the policy of ethnic cleansing was committed against the Palestinian People particularly between 1948 and 1949. This policy is still conducted differently until now.

\section{c) Antonyms}

The contradiction is found in his speech. For example, “... the most important thing is establishing a free state of Palestine - it is a holy right for the Palestinian people" confirms the eligibility of the Palestinian's right of establishing the state; however, “... we don't aim at delegitimizing the Israel state but at establishing the state of 
Palestine ..." shows that he contend the Palestinians' right of establishing the Palestinian state and implicit recognition of Israel state- a state that has legitimacy.

\subsection{The Analysis Level}

\section{a) The level of Grammatical Structure}

Table 7. The frequencies and percentages of the level of grammatical structure in President Abbas' address

\begin{tabular}{lll}
\hline Verb & Frequency & $\%$ \\
\hline Present & 89 & 39 \\
Past & 30 & 13.2 \\
Future & 8 & 3.5 \\
Imperative (command) & 2 & 0.9 \\
Passive verb & 24 & 10.5 \\
Nominal sentence & 37 & 16.2 \\
Verbal sentence & 38 & 16.7 \\
Total & 228 & 100 \\
\hline
\end{tabular}

The previous table shows that the present verb has gotten the first place at $39 \%$ and frequency of 89 . Secondly, the verbal sentence "Al jumla tul Fe $\xi$ liyya" gets $16.7 \%$ and frequency of 38 ; the verbal sentence states the "renewal and occurrence", for example, “... tureed mowasalet saytaratuha ala akhsab aradeena ..." [it wants to keep controlling the most of our more fertilized lands...], “... tarfudu qiyam dawlat filasteen ..." [it declines the establishment of the Palestine State ...], and “... tatabaw'a filasteen makanuha almostahaq bayn umam al aalam ..." [Palestine took its deserved place among the world's nations].

Thirdly, the nominal sentence gets $16.2 \%$ and a frequency of 37 and that sentence states the activity and vitality. For example, "inna Israel tarfodu inhaa' al ihtilal ..." [Israel refuses to end the occupation], and in majlesu al?amn motalab bisra' issdar ..." [the security council has to quickly issue ...]. President Abbas uses these sentences to mix between the renewal, the activity and freedom so that his speech may have greater influence on the addressees.

Fourthly, the past verbs get $13.2 \%$ and a frequency of 30 , which indicates, to the relation between the speech and its production time and the influence of the action on the speaker. The subject of the speech is the speaker's message not the past action, which was mentioned to function as a secondary aim of the speech subject. Abbas wanted to look at the present and future, so he used the present verb to denote to action and the communication between the speaker and the addressee together.

Fifth, the passive verbs get $10.5 \%$ and a frequency of 24 , for example, "to destroy", "to impede", "to establish", "to announce", and "to be destroyed".

Sixth, the future verbs get $3.5 \%$ and a frequency of 8 , for example, “will appear", "will rush", "will be", "will carry on", and "will advise"; all of these verbs are present verbs, but they are preceded by "will" of futurity to denote the close time. The politicians are employing the future verb in their speeches to push the political movement forward and confirm that they are interested in the future and present unchangeable.

Seventh, the imperative verbs get $0.9 \%$ and a frequency of 2 , which are "prevent" and "support". Abbas asked the international community to stop a will-be new nakba in the Holy Land and to support the establishment of Palestinian State.

\section{b) The level of connotation}

\section{Level of the connotational structures}

The connotational level reflects the vocabularies, the structures, and its relation to the discourse subject and its effect on the connotation, and it can be divided into two types:

\section{- The level of major connotaional structures:}

The sentences and structures of Abbas's speech are linked as one theme until the end of the speech, "supporting the establishment of the Palestinian state". The construction of the speech is coherent in its general form, so the subject links the vocabularies and structures tightly from its beginning to the end. He began the speech with appreciating the supportive words of the heads of all delegations of the member countries to achieve the peace that will secure the inalienable national rights of the Palestinian people. He carried on speaking about: the dangers of the Israeli settlement, the Israeli occupation targeting Jerusalem and its surroundings, the 
responsibility of the international community towards the Palestinian people and their prisoners, the Israeli blockade, the resumption of negotiations, the Israeli refusal of the two-state solution, the Israeli measures to keep the occupation, the opportunity to save the peace, the constituents of just solution of the Israeli-Palestinian conflict, the holiness of the right of the establishment of the Palestinian state, the misery of the Palestinian nakba, and the Palestinian stance on the continuous Israeli occupation. These axes of the speech have formed the general thematic frame; the speech was sequenced and well-arranged from one point to another.

\section{- The minor connotaional structures level:}

- The field of peace, rights and independence: achieving the just peace, for the sake of freedom, independence, and peace, people asking for their rights, our national rights, and the independent, free State of Palestine.

- The field of defense and conflict: the foundations of conflict resolution, the core components of the conflict resolution, the odyssey of their steadfastness and eternal survival, and the continuity of the popular resistance.

- The field of Palestine and its people: the Palestinian people, the Palestinian citizens, the occupied Palestinian territories, and State of Palestine.

- The field of politics and religion: the policy of war, occupation, and settlement, political measure, the religious conflict, and using the monotheistic religions.

\subsection{The Rhetorical Analysis Method}

The connotation and its rhetorical aspects: there are many rhetorical connotations in the speech, for example, metonymy, and metaphor, in order to affect the addressees and convince them of the subject of the speech. The next table shows the rhetorical connotations:

Table 8. The rhetorical analysis method in the speech of President Abbas' address

\begin{tabular}{|c|c|c|c|}
\hline Negative & Positive & Rhetorical Aspect & The Sentence \\
\hline negative & & To pour its hatred & To pour its hatred against the trees, fields and plantings \\
\hline negative & & legitimate neonate racial climate & It's legitimate neonate for racial climate to fuel the culture of incitement \\
\hline negative & & saturated with hatred & The extremists' fatwas saturated with hatred \\
\hline & positive & $\begin{array}{l}\text { and the gorgeous scene engraved in } \\
\text { human minds }\end{array}$ & $\begin{array}{l}\text { Change the historic character and the gorgeous scene engraved in human } \\
\text { minds }\end{array}$ \\
\hline negative & & suffocates the city & The barriers and walls siege that suffocates the city \\
\hline negative & & The Israeli policy pours & The Israeli policy pours as a whole into one thing: weakening the authority \\
\hline \multirow[t]{5}{*}{ negative } & & $\begin{array}{l}\text { stoking fire hot explosive spots fuel to the } \\
\text { extremists }\end{array}$ & $\begin{array}{l}\text { That means stoking fire in a very sensitive zone that is full of hot explosive } \\
\text { spots which are fuel to the extremists }\end{array}$ \\
\hline & positive & opened a skylight & We opened a skylight in the deadlock \\
\hline & positive & to break the cycle & The efforts contributing to break the cycle of deadlock \\
\hline & positive & the spirit of reconciliation & $\begin{array}{l}\text { the two-state solution representing the spirit and essence of the historical } \\
\text { reconciliation }\end{array}$ \\
\hline & positive & peacemaking & For the sake of peacemaking \\
\hline negative & & emptying the contents of the agreement & Israeli measures that aims at emptying the contents of the agreement \\
\hline \multirow[t]{2}{*}{ negative } & & eradication and ethnic cleansing & $\begin{array}{l}\text { License for the occupation to continue the policy of eradication and ethnic } \\
\text { cleansing }\end{array}$ \\
\hline & positive & $\begin{array}{l}\text { to save the two-state solution and to } \\
\text { salvage peace }\end{array}$ & $\begin{array}{l}\text { It may be the last chance to save the two-state solution and to salvage } \\
\text { peace }\end{array}$ \\
\hline negative & & Sterile & $\begin{array}{l}\text { Repeated experiences of negotiations with the Israeli government are } \\
\text { sterile }\end{array}$ \\
\hline negative & & $\begin{array}{l}\text { a failure cloning to promote the } \\
\text { occupation }\end{array}$ & $\begin{array}{l}\text { Negotiations without a clear reference means a failure cloning and a cover } \\
\text { to promote the occupation and end the dying peace process }\end{array}$ \\
\hline negative & & The flaming reality & The flaming reality in our country \\
\hline negative & & they were uprooted from their land & $\begin{array}{l}\text { Displacement and refugee camps to which they were expelled after they } \\
\text { were uprooted from their land }\end{array}$ \\
\hline negative & & motionless life & They are waiting for the moment to resume the motionless life \\
\hline negative & & the interrupted journey & They complete the interrupted journey \\
\hline negative & & broken dreams & To repair broken dreams \\
\hline negative & & To correct the historical maltreatment & To correct the historical maltreatment \\
\hline negative & & at risk of dispossession & They see their home and their present and future at risk of dispossession \\
\hline
\end{tabular}


The previous table shows the rhetorical connotations in the speech. For example, "the spirit and essence of the historical reconciliation," has connotaional meaning because the reconciliation has no spirit, but he means the historical reconciliation will not be achieved without a two-state solution. In, "It may be the last chance to save the two-state solution and to salvage peace" the speaker means the international community's recognition of the State of Palestine will achieve the peace and two states of Palestine and Israel. In, "displacement and refugee camps to which they were expelled after they were uprooted from their land" it is clear that the human cannot be rooted, but he wanted to convey the idea of the expulsion of the Palestinians from their land. Also, in "they are waiting for the moment to resume the motionless life" it is known that the life cannot be stopped, but he means the return of refugees to their land from which they were expelled, and that their lives will be renewed. The speaker says, "to correct the historical maltreatment", but the maltreatment cannot be corrected. He means that the people will get their own rights and their right of recognition of the Palestinian State. In his "they see their home and their present and future at risk of dispossession" in reality, the home, present, and the future can never be taken, yet he means if the international community does not recognize the right of the establishment of a Palestinian state and the rights of the Palestinian people, that will mean the loss of their home, present and future. All the previous sentences in the table have a similar analysis.

In addition, the table indicates that President Abbas used both positive and negative expressions in his speech, and that was not arbitrary. He did that on purpose to reflect the current situation or social context. Clearly, the president employed the positive expressions to reflect future expectations, whereas he used negative, creative expressions to reflect the current situation.

\section{Results of Study}

According to the analysis of the Palestinian Authority President Abbas' address to the UN General Assembly in New York, these are the results:

1) The sentences of the speech were cohesive and coherent: the speaker moved from one topic to another in sequence.

2) The speaker used attached, detached, speaker and, absent pronouns as well as conjunctions to help build a joint ground of understanding between the speakers and addressees and make the addressees joined among the progressive meanings with each other.

3) Using demonstrative pronouns makes the address interactive. It create a link the previous and the following ideas, they contribute to consistency of text and being understood by the listener.

4) The speaker employed present verbs to show the relation between the speech and its production time, and the influence of events on the speaker. He used the past, present, and future to confirm the action and communication between the speaker and listener with each other.

5) The discourse tends towards real framing to mix between the renewal, the activity, and freedom so that the speech will have a great influence on the addressees.

6) The president demonstrated the ability to effectively communicate with the listeners through the persuasive means that he used, for example, connotation, the grammar, structure, and rhetoric.

7) The linguistic eloquence includes the clarity of meaning, ease of wording, appropriateness of the syntax, and attractive style.

\section{References}

Brown, G., \& Yule, G. (1983). Discourse analysis. Cambridge: CUP. http://dx.doi.org/10.1017/CBO9780511805226

Cook, G. (1989). Discourse. Oxford: Oxford University Press.

Crystal, D., \& Davy, D. (1969). Investigating English style. Longman: New York.

Fairclough, N. (2001). Language and Power. London: Longman.

Johnstone, B. (2002). Discourse Analysis. Oxford: Blackwell.

Khader, K. T. (2000). Style in drama: A Semiolinguistic perspective. New Delhi: Bahri Publication.

Stubb, M. (1983). Discourse analysis: The sociolinguistic analysis of natural language. Chicago: University of Chicago press.

Thomas, L., Wareing, S., Singh, I., Peccei, J. S., Thornborrow, J., \& Jones, J. (2004). Language, society and power: An Introduction. New York: Routledge. 
Van Dijk, T. A. (2008). Discourse and power. Basingstoke: Palgrave.

Wodak, R., \& Meyer, M. (2009). Methods of Critical Discourse Analysis. London: Sage.

Yule, G. (1996). Pragmatics. Cambridge: CUP.

\section{Copyrights}

Copyright for this article is retained by the author(s), with first publication rights granted to the journal.

This is an open-access article distributed under the terms and conditions of the Creative Commons Attribution license (http://creativecommons.org/licenses/by/3.0/). 